RESIDENT

\& FELLOW

SECTION

Section Editor

Mitchell S.V. Elkind,

MD, MS

Joel Morgenlander, MD

Cheryl Bushnell, MD, MHS

Address correspondence and reprint requests to Dr. Joel Morgenlander, Professor of Medicine (Neurology), Box 3394, Duke University Medical Center, Durham, NC

Supplemental data at www.neurology.org

\section{Education Research: Neurology continuity clinic Improving the timing of the experience}

The Neurology Review Committee (RC) mandates continuity clinic for adult neurology residency training programs. Most neurologic patients, however, are seen in return every few months and emergencies are not seen in continuity clinic. Residents on inpatient rotations leave their rotation to go to clinic, resulting in discontinuity of inpatient care, extra handoffs, and additional distractions in clinic.

Our objective was to compare the traditional weekly schedule for the neurology resident continuity clinic to a new schedule favoring more clinic time during outpatient rotations and less time in clinic during inpatient rotations.

METHODS With the permission of the Neurology RC, we devised a pilot study. Duke Institutional Review Board waiver was obtained. In the first 6-month block, three of the first-year neurology residents attended weekly continuity clinic (standard track), and the other two attended two clinics/week on outpatient rotations, one clinic/week on ward rotations, and no clinics on Neurology-intensive care unit and inpatient consult rotations (study track). The residents switched to the opposite track during the subsequent 6-month block. Numbers of new and return patients seen were compared between blocks. The vast majority of return patients had been seen initially by the same resident. Patients known to the practice who need to be seen urgently or who have been seen by residents who have graduated were seen as returns. Residents and faculty completed a questionnaire to assess their satisfaction with the new schedule (see appendix e- 1 on the Neurology ${ }^{\circledR}$ Web site at www.neurology.org).

RESULTS There was no significant difference in the number of new and return patients seen comparing the 6-month blocks (table).

\begin{tabular}{|lccl|}
\hline Table New and return patients seen during continuity clinic & \\
Clinic variables & $\begin{array}{l}\text { Standard track, } \\
\text { median (range) }\end{array}$ & $\begin{array}{l}\text { Study track, } \\
\text { median (range) }\end{array}$ & p Value \\
Number of clinics & $16(14,17)$ & $14(11,20)$ & 0.8 \\
Number of new patients & $11(5,18)$ & $13(7,15)$ & 0.9 \\
Number of return patients & $20(19,36)$ & $20(20,32)$ & 1 \\
New patients/resident & $0.65(0.36,1.06)$ & $0.72(0.63,1.00)$ & 0.7 \\
Return patients/resident & $1.36(1.18,2.12)$ & $1.6(1.00,1.85)$ & 0.7 \\
Total patients/resident & $2.24(1.71,2.76)$ & $2.35(1.70,2.85)$ & 0.9 \\
\hline
\end{tabular}

*Each resident had 6 months in each track.
Resident and faculty satisfaction. The new schedule was favored by 3 of 5 residents ( 2 residents were neutral) and 13 of 15 faculty.

Questionnaire comments. Advantages noted on the questionnaires of the new schedule included better care of inpatients, less disruption of schedules for residents pulled to cover consults, and fewer disruptive pages in the clinic when the residents are more outpatient based.

The major disadvantage of the new system was difficulty in scheduling patients due to more variability in the resident clinic schedule.

DISCUSSION Our pilot study showed that the total number of new and return patients seen by neurology residents in continuity clinic can be kept stable while allowing more flexibility in clinic session scheduling. Residents and faculty favored the new schedule for continuity clinic over the traditional schedule.

Patient satisfaction scores may be lower when residents are more distracted due to fatigue or having to answer additional pages such as on an inpatient service. ${ }^{1}$ Our residents' satisfaction with their ability to attend to their patients, whether on the ward or in clinic, was improved with the new schedule.

With the development of more flexible residencies such as the R25 pathway, more programs will want to develop flexibility in scheduling for the continuity experience. While we have no plans for further study, other programs should be encouraged to develop alternative schedules and share their experience.

We recommend that the Neurology RC allow neurology programs to submit alternative schedules for resident continuity clinic as long the total number of clinics each year is held constant and the plan supports continuity in patient care.

\section{ACKNOWLEDGMENT}

The authors thank the Duke Neurology faculty and residents, Gina Murray, Gina Hawley, and Paul Lester for support with this project.

\section{REFERENCE}

1. Hoellein AR, Feddock CA, Griffith $\mathrm{CH}$, et al. Are continuity clinic patients less satisfied when the resident is postcall? J Gen Intern Med 2004;19:562-565. 


\title{
Neurology
}

\author{
Education Research: Neurology continuity clinic: Improving the timing of the \\ experience \\ Joel Morgenlander and Cheryl Bushnell \\ Neurology 2009;72; 43 \\ DOI 10.1212/01.wnl.0000343957.47843.3a
}

\section{This information is current as of March 2, 2009}

\section{Updated Information \& Services}

Supplementary Material

References

Citations

Subspecialty Collections

Permissions \& Licensing

Reprints including high resolution figures, can be found at: http://n.neurology.org/content/72/9/e43.full

Supplementary material can be found at: http://n.neurology.org/content/suppl/2009/03/02/72.9.e43.DC1

This article cites 1 articles, 0 of which you can access for free at: http://n.neurology.org/content/72/9/e43.full\#ref-list-1

This article has been cited by 1 HighWire-hosted articles: http://n.neurology.org/content/72/9/e43.full\#\#otherarticles

This article, along with others on similar topics, appears in the following collection(s):

\section{All Education}

http://n.neurology.org/cgi/collection/all_education

Methods of education

http://n.neurology.org/cgi/collection/methods_of_education

Information about reproducing this article in parts (figures,tables) or in its entirety can be found online at:

http://www.neurology.org/about/about_the_journal\#permissions

Information about ordering reprints can be found online:

http://n.neurology.org/subscribers/advertise

Neurology ${ }^{\circledR}$ is the official journal of the American Academy of Neurology. Published continuously since 1951, it is now a weekly with 48 issues per year. Copyright. All rights reserved. Print ISSN: 0028-3878. Online ISSN: 1526-632X.

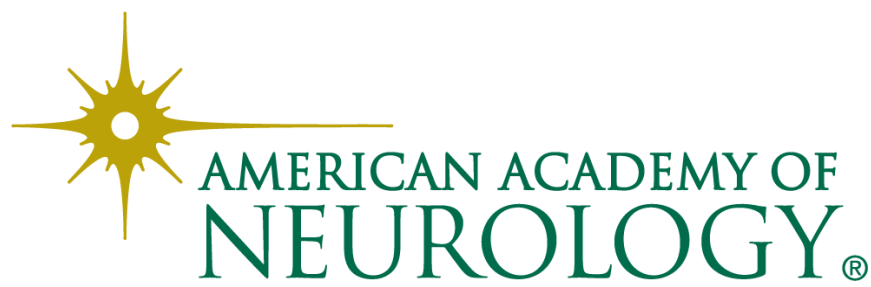

